\title{
Carbon Black and Multi-Walled Carbon Nanotube Supported Cobalt for Anion Exchange Membrane Fuel Cell
}

\author{
Van Men Truong ${ }^{1}$, Chih-Wei Yang ${ }^{1}$ and Hsiharng Yang ${ }^{1,2, *}$ \\ ${ }^{1}$ Graduate Institute of Precision Engineering, National Chung Hsing University, 145 Xingda Road, South \\ District, Taichung City 402, (R.O.C)., Taiwan \\ ${ }^{2}$ Innovation and Development Center of Sustainable Agriculture (IDCSA), National Chung Hsing University, \\ 145 Xingda Road, South District, Taichung City 402, (R.O.C)., Taiwan
}

\begin{abstract}
Carbon black (CB) and multi-wall carbon nanotube (MWCNTs) supported cobalt, namely, CoPc/CB and $\mathrm{CoPc} / \mathrm{MWCNTs}$, respectively, with different metal loads was synthesized and used as the cathode catalyst for anion exchange membrane fuel cells. The prepared catalysts were characterized using X-ray diffraction and scanning electron microscopy. The surface morphology analysis revealed heterogeneous cobalt distribution on the carbon support. Cyclic Voltammetry was also studied to investigate the best combination ratio. The results indicated that the electrochemically largest active surface area was observed when 30 and $40 \mathrm{wt} \%$ cobalt was combined with $70 \mathrm{wt} \%$ CB and 60 wt $\%$ MWCNTs, respectively. The anion exchange membrane fuel cell performance showed that both cathode catalysts exhibited the highest peak power density at $40 \mathrm{wt} \% \mathrm{t}$. Co load. The peak power density of $55 \mathrm{~mW} / \mathrm{cm}^{2}$ at 0.4 volts was obtained using CoPc/CB. Meanwhile, the promising catalyst CoPc/MWCNTs only produced $35 \mathrm{~mW} / \mathrm{cm}^{2}$, which did not meet the expectation. According to some references, the alkaline fuel cell performance might be bothered by the acid residues, sulfates and nitrates produced by the MWCNT purification process.
\end{abstract}

Keywords: Anion Exchange Membrane Fuel Cell, multi-walled carbon nanotubes, carbon black, cobalt phthalocyanine, catalyst.

\section{INTRODUCTION}

Proton-exchange membrane fuel cells (PEMFCs) have been recognized as promising energy source systems due to their high energy-conversion efficiency, high power density, and very low pollutant emission [14]. However, the crucial drawbacks of PEMFCs, such as the high cost caused by platinum used as catalyst (around $45 \%$ of the entire system cost) and the low durability of metal catalysts under acidic conditions, are restricting their commercialization $[5,6]$. In recent years, anion exchange membrane fuel cells (AEMFCs) have been considered a new development alternative to state-of-the-art PEMFCs. Compared to PEMFCs, one of the key advantages of AEMFCs is the possibility of using non-PGM catalysts for hydrogen oxidation (HOR) and oxygen reduction reactions (ORR) which can reduce their cost [7-10].

Efficient and cost-effective catalysts for cathodic oxygen reduction are a critical research issue. A significant amount of work has been done on using non-precious metals for ORR in various media. In the past two decades, cobalt phthalocyanine (CoPc) has been explored as a non-precious metal catalyst for the ORR used in energy storage and conversion devices

*Address correspondence to this author at the Innovation and Development Center of Sustainable Agriculture (IDCSA), National Chung Hsing University, 145 Xingda Road, South District, Taichung City 402, (R.O.C)., Taiwan; Tel: +886-4-22873629; Fax: +886-4-22858362; E-mail: hsiharng@nchu.edu.tw
[11-13]. These explorations showed that heat-treated CoPc containing carbon yields a catalytically active electrode material in both alkaline and acidic electrolyte environments. CoPc was initially applied in nonaqueous Li-air batteries as the cathode catalyst [11]. Abraham et al. discovered that a catalyzed cathode composed of carbon black and CoPc pyrolyzed at temperatures between 600 and $800^{\circ} \mathrm{C}$ exhibited catalytic activity for ORRs resulting in increased Li-air cell discharge load voltage and discharged cell rechargeability improvement. Similar work was also demonstrated by Matthew and coauthors. The full $\mathrm{O}_{2}$ to $\mathrm{Li}_{2} \mathrm{O}$ reduction in a Li-air cell can be achieved using cobalt phthalocyanine catalyzed carbon cathode [12]. Moreover, the CoPc-containing carbon black electrode which results in carbon black/CoPc mixture pyrolysis at $600^{\circ} \mathrm{C}$ effectively lowered the gap between the discharge and charge voltage plateaus, leading to battery performance improvement. The structural changes in active carbon+cobalt phthalocyanine catalyst were observed during pyrolysis in the $500-800^{\circ} \mathrm{C}$ temperature using infrared spectroscopy, XRD and DTG analysis [13]. They found that the presence of cobalt at lower pyrolysis temperatures decreases the oxygen diffusion limitations in $0.5 \mathrm{M} \mathrm{H}_{2} \mathrm{SO}_{4}$. Muller and co-workers [14] characterized the $\mathrm{CoPc}$ catalyst for fuel cell applications. With XPS and NEXAFS analysis, the results revealed that the $\mathrm{CoPc}$ molecules can be stabilized up to an annealing temperature of $300^{\circ} \mathrm{C}$. In 
addition, there was a significant reduction in the $\mathrm{CoN}_{4}$ complex and the number of transferred electrons was increased for samples pyrolyzed at $800^{\circ} \mathrm{C}$ and $1000^{\circ} \mathrm{C}$. The oxygen reduction reaction mechanism of the $\mathrm{CoPc} / \mathrm{C}$ catalyst was studied using a rotating disk electrode (RDE). The rotating ring-disk electrode (RRDE) techniques and density functional theory (DFT) calculations in the $0.1 \mathrm{M} \mathrm{NaOH}$ solution [15]. The CoPc/C catalyst prepared with the acid solvent and without heat-treatment showed that the mass transport limiting ORR current was reached at the potential less than $0.2 \mathrm{~V}$ vs. $\mathrm{Hg} / \mathrm{HgO}$. Additionally, based on DFT calculations it was predicted that $\mathrm{OH}$ adsorption is more energetically favorable than $\mathrm{O}_{2}$ adsorption on CoPc catalyst molecules. To the best of our knowledge, AEMFC performance has not been studied using $\mathrm{CoPc} / \mathrm{C}$ as cathode catalyst as well as the cobalt load effect on ORR under basic conditions.

The present work is an investigation of the cobalt load effects supported on carbon black (CB) and multiwall carbon nanotubes (MWCNTs) used as ATMFC cathode catalyst. The CoPc/CB and CoPc/MWCNTs were simply synthesized and characterized using X-ray diffraction (XRD) and transmission electron microscopy (SEM). The cyclic voltammetry (CV) was used to evaluate the CoPc/CB and CoPc/CNTs catalyst electrochemical surface area prepared with different cobalt metal loads. The cobalt load influence on AEMFC performance is tested and reported in detail.

\section{EXPERIMENTAL}

\subsection{CoPc/CB and CoPc/MWCNTs Catalyst Synthesis}

Before catalyst preparation raw CNTs (obtained from Carbon Energy Technology Co., Ltd) were pretreated in an acid mixture of $20 \% \mathrm{H}_{2} \mathrm{SO}_{4}$ and $20 \%$ $\mathrm{HNO}_{3}$ with a volume ratio of 3:1. This treatment creates functional groups, cuts the tubes, eliminates contaminants and opens the CNT caps. Raw CNTs with an outer diameter of $4 \sim 30 \mathrm{~nm}$, length of about $1 \mu \mathrm{m}$, and $2 \sim 50$ concentric tubes were refluxed at 120 ${ }^{\circ} \mathrm{C}$ for $2 \mathrm{~h}$ in the acid mixture. After that, the suspension was filtered and washed with distilled water several times, followed by drying at $120^{\circ} \mathrm{C}$ for $10 \mathrm{~h}$.

Catalysts with different Co content were prepared using the wetness impregnation method as follows. Commercial CoPc powder (Aldrich Chemistry) was dissolved in isopropanol alcohol and sonicated for $30 \mathrm{~min}$ at room temperature. The appropriate amount of
Vulcan XC-72R carbon black (Cabot) or functionalized MWCNTs was then added and the solution was vigorously stirred for $1 \mathrm{~h}$. The mixture was next dried at $100^{\circ} \mathrm{C}$ in a vacuum oven. The catalyst powder was placed into a quartz boat and heated for $2 \mathrm{~h}$ at $800^{\circ} \mathrm{C}$ in a horizontal quartz furnace under a continuous argon flow.

\subsection{Characterization and Electrochemical Measurement}

The as-synthesized catalyst materials were characterized using scanning electron microscopy (SEM, S-3400N) and high-resolution X-ray diffractometer (HRXRD, BRUKER D8 SSS). CV measurements for the catalysts were carried out in 0.1 $\mathrm{M} \mathrm{KOH}$ solution prepared from $\mathrm{KOH}$ pellets using Zennium $\mathrm{E}$ workstation in a three-electrode configuration. The experiments were performed at room temperature consisting of cathodic gas diffusion electrode (GDE) with the area of $6 \mathrm{~cm}^{2}$ as the working electrode, $\mathrm{Ag} / \mathrm{AgCl}(0.200 \mathrm{~V}$ vs. SHE) as the reference electrode and a Pt wire as the counter electrode. The electrode potentials were converted into RHE.

\subsection{Fuel Cell Test}

The $40 \% \mathrm{Pt} / \mathrm{C}$ (anode catalyst, Tanaka) or asprepared catalyst powder (cathode catalyst) was submerged in a solution containing aQAPS-S ${ }_{14}$ ionomer, DI water and IPA (Isopropyl alcohol) with a weight ratio of 1:0.3:13:26. The catalyst ink was sonicated for $60 \mathrm{~min}$ to promote homogenization and then coated onto the MPL GDL surface (GDL340, CeTech, Taiwan) by hand-brushing on an $80^{\circ} \mathrm{C}$ hot plate. The catalyst load was kept at $0.5 \mathrm{mgcm}^{-2}$ on both the anode and cathode sides.

AEMs used in this work were aQAPS-S $\mathrm{S}_{8}$ having a thickness of $40 \mu \mathrm{m}$ in the dry form. As the membrane was available in chloride form $\left(\mathrm{Cl}^{-}\right)$, pre-treatment was performed to convert it into the hydroxide form $\left(\mathrm{OH}^{-}\right)$by soaking for $24 \mathrm{~h}$ in $1 \mathrm{M} \mathrm{KOH}$. The prepared electrodes were also dipped in $1 \mathrm{M} \mathrm{KOH}$ solution to transform the binder from $\mathrm{Cl}^{-}$into $\mathrm{OH}^{-}$form. Finally, the aQAPS membrane was sandwiched between the two electrodes without hot pressing. The active electrode area was $25 \mathrm{~cm}^{2}$. The MEA was secured between two graphite plates with machined triple serpentine flow channels $(1 \mathrm{~mm}$ channel width, $1 \mathrm{~mm}$ channel height, and $1.5 \mathrm{~mm}$ rib width) and gold coated copper current collector plates with gaskets. Teflon gaskets with thickness required to give $20-30 \%$ GDL compression 
were used. The fixture was sealed using bolts with a constant torque of $1.4 \mathrm{Nm}$. A fuel cell testing system (FCED-PD50 test station, Asia Pacific Fuel Cell Technologies, Ltd.) was operated at the cell temperature of $50^{\circ} \mathrm{C}$ with $90 \%$ humidified $\mathrm{H}_{2}$ and $\mathrm{O}_{2}$ flowing at 0.2 and 0.4 slpm, respectively.

\section{RESULTS AND DISCUSSION}

\subsection{Catalyst Characteristic}

Bulk structural information for CoPc/MWCNTs and $\mathrm{CoPc} / \mathrm{CB}$ electro catalyst composites was obtained using $\mathrm{XRD}$ as presented in Figures $\mathbf{1 a}$ and $\mathbf{b}$. The broad peak at around $2 \theta$ value of about $25^{\circ}$ can be assigned to carbon (002) facet. The diffraction carbon peak at $25^{\circ}$ was found to decrease with the presence of the Co metal load. This could be the result of a strong interaction between MWCTN or CB support and the deposited Co particles indicating a good metal particles distribution on the supports. The figures show the two characteristic peaks at $2 \theta$ value around $44.2^{\circ}$ and $51.5^{\circ}$ in the synthesized catalysts, which could be assigned to $\mathrm{Co}(111)$ and $\mathrm{Co}(200)$ plane [16]. This revealed that cobalt in the CoPc/MWCNTs and CoPc /CB catalysts exists mainly as metallic $\alpha$-Co with a face-centered cubic (fcc) structure. Moreover, the XRD pattern indicated that the Co particles present in the carbon-supported CoPc catalysts are in metallic form since no characteristic oxide peak was found.

The catalyst surface was further characterized using scanning electron microscopy (SEM) and the representative SEM micrographs are presented in Figure 2. Scanning electron micrographs showed that the catalyst particles are heterogeneously dispersed on the MWCNTs and CB, confirming the presence of $\mathrm{Co}$ in the prepared catalysts.
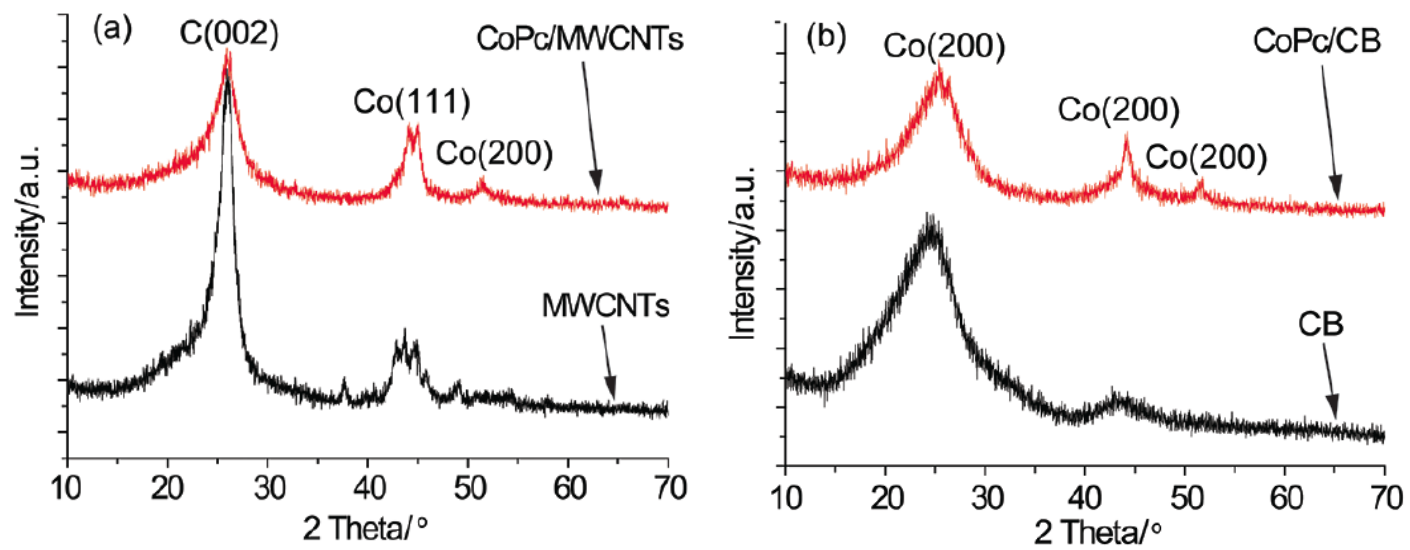

Figure 1: XRD spectrum patterns. (a) CoPc/MWCNTs. (b) CoPc/CB.
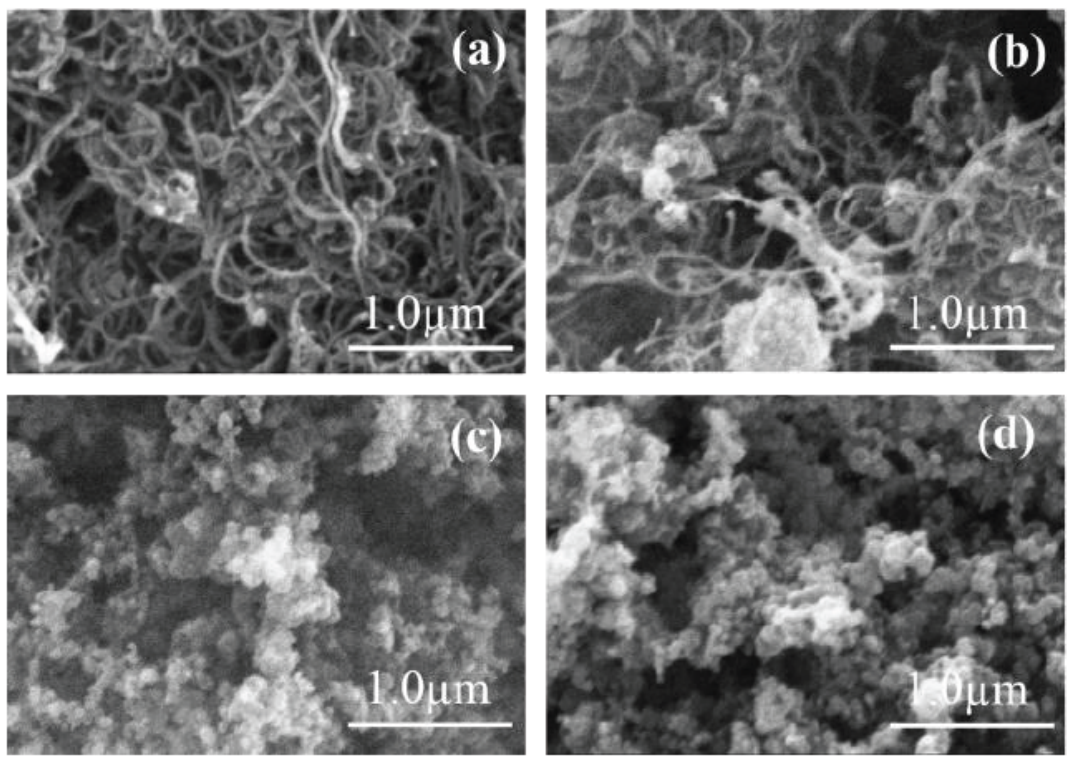

Figure 2: Surface morphology SEM images. (a) MWCNTs. (b) CoPc/MWCNTs after $800^{\circ} \mathrm{C}$. (c) $\mathrm{CB}$. (d) $\mathrm{CoPc} / \mathrm{CB}$ after $800^{\circ} \mathrm{C}$. 

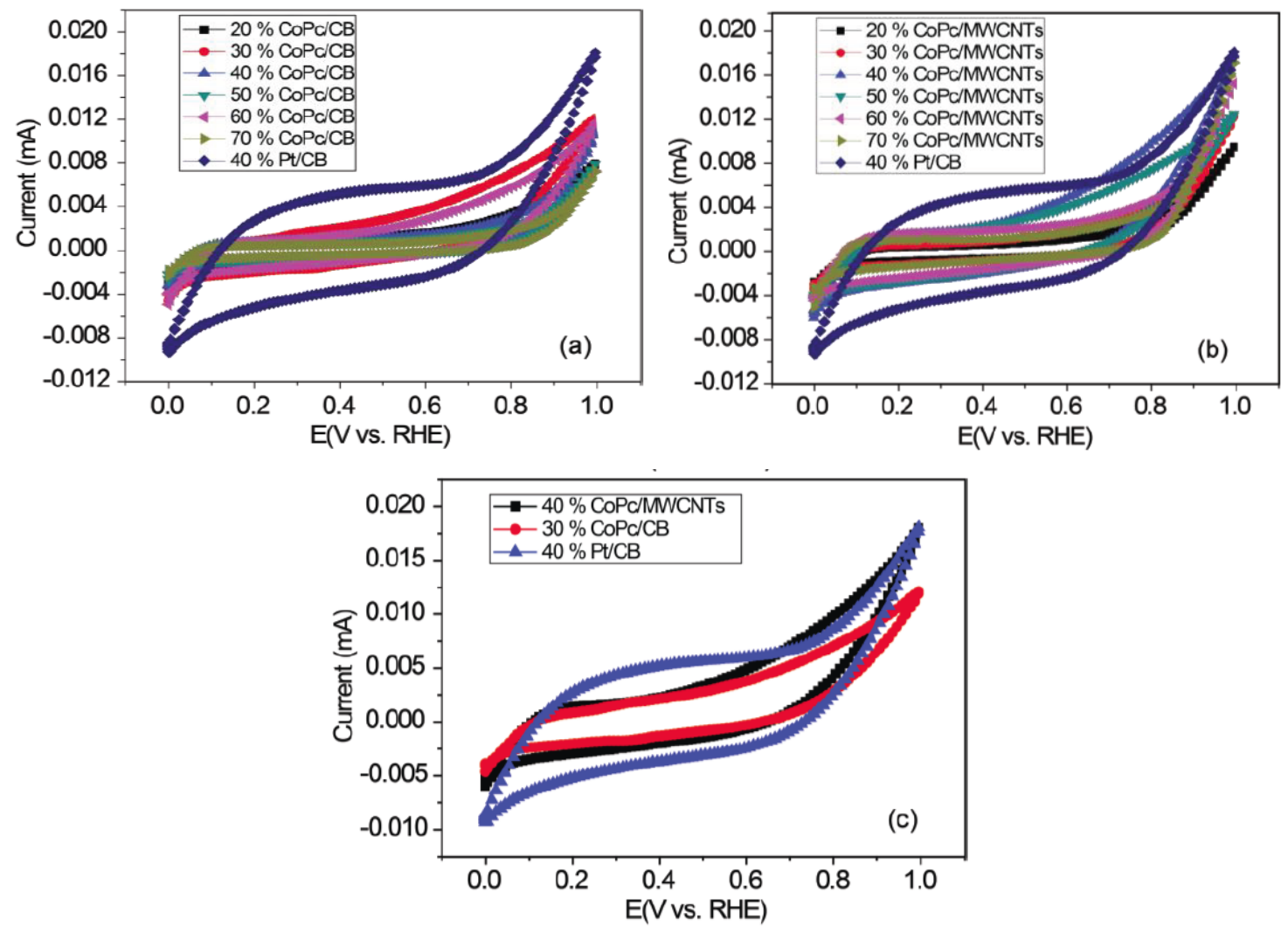

Figure 3: $\mathrm{CVs}$ monitored on the synthesized catalysts in $0.1 \mathrm{M} \mathrm{KOH}$ solution at scan rate $200 \mathrm{mV} / \mathrm{sec}$ and $25^{\circ} \mathrm{C}$. (a) $\mathrm{CoPc} / \mathrm{CB}$. (b) CoPc/MWCNTs. (c) CVs comparison.

\subsection{Measurement Results}

Figures $3 \mathbf{a}, \mathbf{b}$, and $\mathbf{c}$ show the measured $\mathrm{CV}$ patterns of the CoPc/MWCNTs and CoPc /CB catalysts in $0.1 \mathrm{M} \mathrm{KOH}$ solution. The $\mathrm{CV}$ curves were related to the hydroxide $\left(\mathrm{OH}^{-}\right)$adsorption/desorption on the active electrode cobalt surface. The purpose of this experiment is to evaluate the electrochemical surface area (ESA) for different Co metal and carbon support weight ratios. Therefore, the scan rate was selected so that redox peaks were not present in the $\mathrm{CV}$ measurements. As depicted in these Figures $\mathbf{3 a - b}$, the largest ESA was observed at 30 and $40 \mathrm{wt} \%$ Co for CB and MWCNT, respectively. At the lower loads, the Co particles lacked distribution across the support surface, resulting in the smaller observed ESA. There is a clear increase in Co coverage on the carbon supports with the increase in load. The ESA is seen to decrease at higher Co loads and this can be explained by the increase in particle agglomeration with increased load [17]. In addition, as shown in Figure 3c, the ESA of CoPc/MWCNTs at the optimized load was larger than that of $\mathrm{CoPc} / \mathrm{CB}$ due to the higher specific surface area [18], indicating that MWCNTs is an effective support for catalysts.

\subsection{AEMFC Testing Results}

An AEMFC single cell using aQAPS as the membrane and the ionomer in electrodes, CoPc/BC or CoPc/MWCNTs and $\mathrm{Pt} / \mathrm{C}$ as the cathode and anode catalysts, respectively, was tested in this work. Such a single cell was operated at $50^{\circ} \mathrm{C}$ under pure $\mathrm{H}_{2}$ and $\mathrm{O}_{2}$ gases of $90 \%$ relative humidity. The polarization and power density curves with different wt $\%$ CoPc/CB and CoPc/MWCNTs cathode catalysts were depicted in Figures $\mathbf{4 a}$ and $\mathbf{b}$. The peak power density reached the highest value with $40 \mathrm{wt} \%$ Co in the catalysts regardless using $\mathrm{CB}$ or MWCNTs support. The best performance of $40 \mathrm{wt} \%$ CoPc/MWCNTs in comparison to 20 and 30 wt.\% CoPc/MWCNTs can be ascribed to the higher electrochemical surface area (ESA) which is in good agreement with the CV test trend. However, in the $\mathrm{CB}$ support case, the possible reason why the biggest ESA achieved at $30 \mathrm{wt} \%$ Co load could not offer the best fuel cell performance may be the lack of active sites due to the lower Co load. Moreover, the number of electrons transferred in the ORR process should be another probable rationale. This explanation, which can be confirmed using CV measurement in oxygen saturated $\mathrm{KOH}$ solution, and the $\mathrm{K}-\mathrm{L}$ plot slope will be explored future works. 

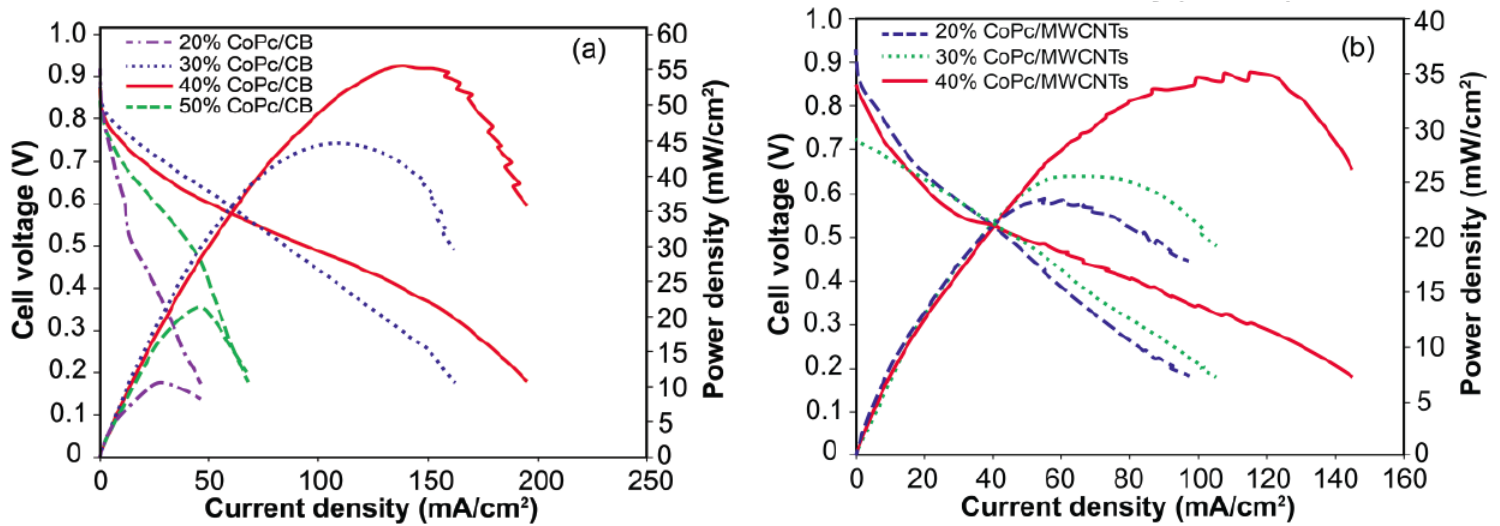

Figure 4: AEMFC polarization and power density curves. (a) CoPc/CB. (b) CoPc/MWCNTs.

Figure 5 shows the polarization and power density curves for a single cell build-up with $\mathrm{Pt} / \mathrm{C}, \mathrm{CoPc} / \mathrm{CB}$ and CoPc/MWCNTs as the cathode catalyst. The maximum power densities were $65 \mathrm{~mW} / \mathrm{cm}^{2}, 55 \mathrm{~mW} / \mathrm{cm}^{2}$ and $35 \mathrm{~mW} / \mathrm{cm}^{2}$ for $\mathrm{Pt} / \mathrm{C}, \mathrm{CoPc} / \mathrm{CB}$, and CoPc/MWCNTs, respectively. In comparison with $\mathrm{Pt} / \mathrm{C}$, $40 \mathrm{wt} \% \mathrm{CoPc} / \mathrm{BC}$ showed appreciated performance with $55 \mathrm{~mW} / \mathrm{cm}^{2}$ compared to $65 \mathrm{~mW} / \mathrm{cm}^{2}$ of the $\mathrm{Pt} / \mathrm{C}$ case. Recently, on the market, the selling prices of the raw carbon black (Vulcan XC-72) and MWCNTs are around 1 US $\$$ and 2 US $\$$ per gram, respectively, and the CoPc material is around 1.4 US\$ per gram as the purchasing amount larger than 1000 grams. According to our catalyst synthesis process, the cost of the $\mathrm{CoPc} / \mathrm{CB}$ and CoPc/MWCNTs will not excess 3 US\$ and 3.5 US\$ per gram, respectively, for industrial production. The price of the commercial Pt/C (40\%wt.\% $\mathrm{Pt} / \mathrm{C}$, Tanaka) is about 80 US\$ per gram. Based on the AEMFC performance testing in this work, one can be estimated the cost of CoPc based catalysts is roughly 27.3 US\$ and 50.1 US\$ per kW for CB and MWCNTs supporters, respectively, while it is almost 615.2 US\$ per kW. This indicates that using $\mathrm{CoPc} / \mathrm{CB}$ and

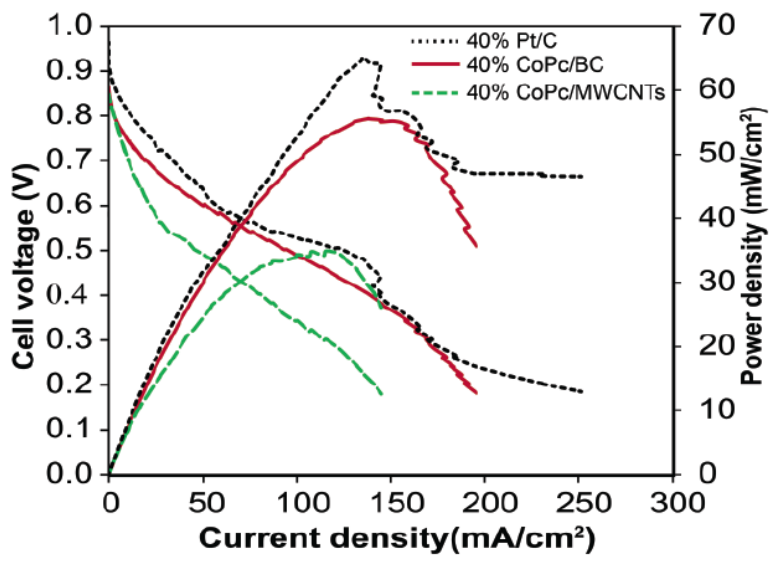

Figure 5: AEMFC polarization and power density curves comparison.
CoPc/MWCNTs catalysts will lead to an approximately 22 and 12-fold cost reduction, respectively, compared by using $\mathrm{Pt} / \mathrm{C}$. Although, using MWCNTs support was expected to be superior to $C B$ in this work due to the high specific surface area and high electrical conductivity of MWCNTs [19], the undesired results were observed and this may be caused by the acidic residuals in the purification process and should be further investigated.

\section{CONCLUSION}

CoPc catalysts supported onto CB and MWCNTs with varying metal loads were prepared using the impregnation method and studied. The $40 \mathrm{wt} \% \mathrm{CoPc}$ exhibited the best AEMFC performance in comparison to lower and higher Co loads regardless using $\mathrm{CB}$ or MWCNTs supports. The $\mathrm{H}_{2}-\mathrm{O}_{2}$ AEMFCs with $\mathrm{CoPc} / \mathrm{CB}$, CoPc/MWCNTs, and Pt/C cathode catalysts showed a peak power density of 55,35 and $65 \mathrm{~mW} / \mathrm{cm}^{2}$, respectively, which suggested that $\mathrm{CoP} / \mathrm{CB}$ is a competitive substitute for $\mathrm{Pt} / \mathrm{C}$ as an AEMFC cathode catalyst. MWCNTs are a promising catalyst support presented unexpected AEMFC performance. The impact of acidic residuals in the pretreatment process may be a possible reason for the underperformed AEMFC tests.

\section{ACKNOWLEDGEMENTS}

This work is funded by the Ministry of Science and Technology of Taiwan under the grant of MOST-1052923-E-005-001-MY3. Also, this work is supported in part by the Ministry of Education, Taiwan, R.O.C. under the Higher Education Sprout Project.

\section{REFERENCES}

[1] Steele $\mathrm{BCH}$, Heinzel A. Materials for fuel-cell technologies. J Nature 2001; 414: 345-352. https://doi.org/10.1038/35104620 
[2] Mehta V, Cooper JS. Review and analysis of PEM fuel cell design and manufacturing. Journal of Power Sources 2003; 114: $32-53$ https://doi.org/10.1016/S0378-7753(02)00542-6

[3] Wu J, Yuan XZ, Martina JJ, Wang H, Zhang J, Shen J, Wu S, Merida W. A review of PEM fuel cell durability: Degradation mechanisms and mitigation strategies. Journal of Power Sources 2016; 335: 162-171.

[4] Fazeli M, Hinebaugh J, Fishman Z, Totzke C, Lehnert W, Manke I, Bazylak A. Pore network modeling to explore the effects of compression on multiphase transport in polymer electrolyte membrane fuel cell gas diffusion layers. Journal of Power Sources 2008; 184: 104-119.

[5] Spendelow S, Marcinkoski J. DOE Fuel Cell Technologies Office Record: Fuel Cell System Cost-2013. https://www.hydrogen.energy.gov/pdfs/14012 fuel_cell_syst em_cost_2013.pdf.

[6] Costamagna P, Srinivasan S. Quantum jumps in the PEMFC science and technology from the 1960s to the year 2000 . Part I. Fundamental scientific aspects. Journal of Power Sources 2001; 102: 242-252. https://doi.org/10.1016/S0378-7753(01)00807-2

[7] Lin BYS, Kirk DW, Thorpe SJ. Performance of alkaline fuel cells: A possible future energy system? Journal of Power Sources 2006; 102: 474-483. https://doi.org/10.1016/j.jpowsour.2006.03.052

[8] Spendelowa JS, Wieckowski A. Electro catalysis of oxygen reduction and small alcohol oxidation in alkaline media. Phys Chem Chem Phys 2007; 9: 2654-2675. https://doi.org/10.1039/b703315

[9] Qiu B, Lin B, Qiu L, Yan F. Alkaline imidazolium- and quaternary ammonium-functionalized anion exchange membranes for alkaline fuel cell applications. J Mater Chem 2012; 22: 1040-1045 https://doi.org/10.1039/C1JM14331J

[10] Varcoe JR, Atanassov P, Dekel DR, Herring AM, Hickner MA, Kohl PA, Kucernak AR, Mustain WE, Nijmeijer K, Scott $\mathrm{K}$, Xuk T, Zhuang L. Anion-exchange membranes in electrochemical energy systems $\dagger$. Energy Environ Sci 2014; 7: 3135-3191. https://doi.org/10.1039/C4EE01303D

[11] Abraham KM, Jiang Z. A Polymer Electrolyte Based Rechargeable lithium/Oxygen Battery. Journal of The Electrochemical Society 1996; 143(1). https://doi.org/10.1149/1.1836378
[12] Trahan MJ, Jia Q, Mukerjee S, Plichta EJ, Hendrickson MA, Abrahama KM. Cobalt Phthalocyanine Catalyzed Lithium-Air Batteries. Journal of The Electrochemical Society 2013; 160: 1577-1586.

https://doi.org/10.1149/2.118309jes

[13] Nikolov I, Vitanova I, Najdenov V, Milusheva T, Vitan T. Effect of pyrolysis temperature of the catalytic activity of active carbon+cobalt phthalocyanine in sulfur dioxide oxidation by oxygen. Journal of Appl Electrochem 1996; 27 : 77-82. https://doi.org/10.1023/A:1026423100998

[14] Müller K, Richter M, Friedricha D, Paloumpa I, Kramm UI Schmeißer D. Spectroscopic characterization of CobaltPhthalocyanine electro catalysts for fuel cell applications. Journal of Solid State Ionics 2012; 216: 78-82. https://doi.org/10.1016/j.ssi.2011.12.013

[15] Chen R, Li HX, Chu De, Wang G. Unraveling Oxygen Reduction Reaction Mechanisms on Carbon-Supported FePhthalocyanine and Co-Phthalocyanine Catalysts in Alkaline Solutions. Journal of Physical Chemistry C 2009; 133: 20689-20697. https://doi.org/10.1021/jp906408y

[16] Yuan X, Hu X, Ding XL, Kong HC. Effects of cobalt precursor on pyrolyzed carbon-supported cobalt-polypyrrole as electro catalyst toward oxygen reduction reaction. Nanoscale Research Letters 2013; 8: 478-488. https://doi.org/10.1186/1556-276X-8-478

[17] Taylor S, Fabbri E, Levecque P, Schmidt TJ, Conrad O. The Effect of Platinum Loading and Surface Morphology on Oxygen Reduction Activity. Journal of Electrocatalysis 7: 2016; 287-296. https://doi.org/10.1007/s12678-016-0304-3

[18] Liu Z, Li ZL, Wang F, Liu JJ, Jing J. Synthesis of multi-walled carbon nanotube supported nickel catalysts by hydrazine reduction and their electro catalytic activity on ethanol electro-oxidation. Journal of Materials Letters 2011; 65: 3396-3398. https://doi.org/10.1016/j.matlet.2011.07.068

[19] Matsumoto T, Komatsu T, Arai K, Yamazaki T. Reduction of $\mathrm{Pt}$ usage in fuel cell electro catalysts with carbon nanotube electrodes. Chem Commu 2004; 840-841.

(c) 2018 Truong et al.; Licensee Lifescience Global.

This is an open access article licensed under the terms of the Creative Commons Attribution Non-Commercial License (http://creativecommons.org/licenses/by-nc/3.0/) which permits unrestricted, non-commercial use, distribution and reproduction in any medium, provided the work is properly cited. 